\title{
Contribution of Excessive Alcohol Consumption to Deaths and Years of Potential Life Lost in the United States
}

Mandy Stahre, PhD, MPH; Jim Roeber, MSPH; Dafna Kanny, PhD; Robert D. Brewer, MD, MSPH; Xingyou Zhang, PhD

Suggested citation for this article: Stahre M, Roeber J, Kanny D, Brewer RD, Zhang X. Contribution of Excessive Alcohol Consumption to Deaths and Years of Potential Life Lost in the United States. Prev Chronic Dis 2014;11:130293. DOI: http://dx.doi.org/10.5888/pcd11.130293 圈.

\section{MEDSCAPE CME}

Medscape, LLC is pleased to provide online continuing medical education (CME) for this journal article, allowing clinicians the opportunity to earn CME credit.

This activity has been planned and implemented in accordance with the Essential Areas and policies of the Accreditation Council for Continuing Medical Education through the joint providership of Medscape, LLC and Preventing Chronic Disease. Medscape, LLC is accredited by the ACCME to provide continuing medical education for physicians.

Medscape, LLC designates this Journalbased CME activity for a maximum of 1 AMA PRA Category 1 Credit(s) ${ }^{\mathrm{TM}}$. Physicians should claim only the credit commensurate with the extent of their participation in the activity.

All other clinicians completing this activity will be issued a certificate of participation. To participate in this journal CME activity: (1) review the learning objectives and author disclosures; (2) study the education content; (3) take the post-test with a $75 \%$ minimum passing score and complete the evaluation at www.medscape.org/journal/pcd; (4) view/print certificate.

Release date: June 26, 2014; Expiration date: June 26, 2015

\section{Learning Objectives}

Upon completion of this activity, participants will be able to:

- Analyze different forms of problem drinking in terms of promoting alcohol-attributable deaths and years of potential life lost

- Evaluate the epidemiology of alcohol-attributable deaths in the United States

- Identify the state with the highest rate of alcohol-attributable deaths and associated years of potential life lost

- Estimate the relative mortality burden of alcohol-attributable deaths in the United States

\section{EDITORS}

Rosemarie Perrin, Technical Writer/Editor, Preventing Chronic Disease. Disclosure: Rosemarie Perrin has disclosed no relevant financial relationships.

\section{CME AUTHOR}

Charles P. Vega, MD, Associate Professor and Residency Director, Department of Family Medicine, University of California, Irvine. Disclosure: Charles P. Vega, MD, has disclosed the following financial relationships: Served as an advisor or consultant for: McNeil Pharmaceuticals

\section{AUTHORS AND CREDENTIALS}

Disclosures: Mandy Stahre, PhD, MPH; Jim Roeber, MSPH; Dafna Kanny, PhD; Robert Brewer, MD, MSPH; and Xingyou Zhang, PhD, have disclosed no relevant financial relationships.

Affiliations: Mandy Stahre, Washington State Department of Health, Olympia, Washington; Jim Roeber, New Mexico Department of Health, Santa Fe, New Mexico; Dafna Kanny, Robert Brewer, Xingyou Zhang, Centers for Disease Control and Prevention, Atlanta, Georgia. 


\section{Abstract}

\section{Introduction}

Excessive alcohol consumption is a leading cause of premature mortality in the United States. The objectives of this study were to update national estimates of alcohol-attributable deaths (AAD) and years of potential life lost (YPLL) in the United States, calculate age-adjusted rates of AAD and YPLL in states, assess the contribution of AAD and YPLL to total deaths and YPLL among working-age adults, and estimate the number of deaths and YPLL among those younger than 21 years.

\section{Methods}

We used the Centers for Disease Control and Prevention's Alcohol-Related Disease Impact application for 2006-2010 to estimate total AAD and YPLL across 54 conditions for the United States, by sex and age. AAD and YPLL rates and the proportion of total deaths that were attributable to excessive alcohol consumption among working-age adults (2064 y) were calculated for the United States and for individual states.

\section{Results}

From 2006 through 2010, an annual average of 87,798 (27.9/100,000 population) AAD and 2.5 million (831.6/100,000) YPLL occurred in the United States. Age-adjusted state AAD rates ranged from 51.2/100,000 in New Mexico to 19.1/100,000 in New Jersey. Among working-age adults, 9.8\% of all deaths in the United States during this period were attributable to excessive drinking, and $69 \%$ of all AAD involved working-age adults.

\section{Conclusions}

Excessive drinking accounted for 1 in 10 deaths among working-age adults in the United States. AAD rates vary across states, but excessive drinking remains a leading cause of premature mortality nationwide. Strategies recommended by the Community Preventive Services Task Force can help reduce excessive drinking and harms related to it.

\section{Introduction}

Excessive alcohol use is the fourth leading preventable cause of death in the United States (1) and costs $\$ 223.5$ billion, or about $\$ 1.90$ per drink, in 2006 (2). Excessive alcohol consumption includes binge drinking (ie, $\geq 5$ drinks on an occasion for men; $\geq 4$ drinks on an occasion for women), heavy weekly alcohol consumption (ie, $\geq 15$ drinks/week for men; $\geq 8$ drinks/week for women), and any drinking by pregnant women or those younger than 21 years (2). Binge drinking, the most common form of excessive alcohol consumption, usually results in acute intoxication and is responsible for over half of deaths and three-quarters of the economic costs of excessive drinking. Excessive drinking is also responsible for many other health and social problems $(3,4)$.

In 2004, the Centers for Disease Control and Prevention (CDC) released an online version of the Alcohol-Related Disease Impact (ARDI) application to allow state public health agencies and other users to assess deaths and years of potential life lost (YPLL) attributable to excessive drinking. By using ARDI, CDC estimated approximately 75,000 deaths and 2.3 million YPLL were due to excessive drinking in the United States in 2001 (5). However, since that time, no comprehensive analysis has been conducted of US deaths and YPLL from excessive alcohol consumption. Furthermore, the ARDI application does not provide rates for death and YPLL from excessive drinking. The assessment of these rates is important because the total number of alcohol-attributable deaths (AAD) and YPLL are known to vary substantially across states (6), as does the prevalence and intensity of binge drinking (3). Finally, the contribution of excessive drinking to deaths among working-age adults (20-64 y) and those younger than 21 years is not well understood, even though excessive drinking is known to be a major cause of premature mortality, resulting in an average of 30 years of life lost per AAD (5).

The objectives of this study were to update previous national estimates of AAD and YPLL in the United States, calculate age-adjusted rates of AAD and YPLL in states, assess the contribution of AAD and YPLL to total deaths and YPLL among working-age adults, and estimate the number of deaths and YPLL that specifically involved those younger than 21 years.

\section{Methods}

We estimated average annual deaths and YPLL from 2006 through 2010 that were attributable to excessive drinking by using the CDC's ARDI online application (6). The methods used in ARDI were developed by a scientific workgroup that comprised experts in alcohol and public health. The details of these methods have been discussed elsewhere (5). Briefly, ARDI estimates AAD by multiplying the number of age- and sex-specific deaths from 54 alcohol-related causes, identified by the underlying cause of death reported on death certificates, by the alcohol-attributable fractions (AAF) for that cause of death. 
The majority of AAF for chronic conditions are calculated by ARDI on the basis of relative risk estimates from metaanalyses and the prevalence of alcohol use at specified risk levels $(7,8)$. Self-reported alcohol use from the Behavioral Risk Factor Surveillance System (BRFSS) (9) was used to capture drinking at levels specified by the meta-analyses, which use slightly higher cut-points for risky drinking than those more commonly used in the United States. For the majority of acute conditions (ie, injuries), ARDI includes a direct estimate of the AAF. AAF for these conditions is based on studies assessing the proportion of deaths from a particular condition that occurred at or above a blood alcohol level of $0.10 \mathrm{~g} / \mathrm{dL}$ (10). In addition, certain conditions (eg, alcoholic cirrhosis of the liver) are by definition $100 \%$ alcohol-attributable and therefore did not need to be estimated. To calculate YPLL attributable to excessive alcohol consumption, the age- and sex-specific AAD estimates for each cause were multiplied by the corresponding estimate of life expectancy based on the age and sex of the decedent.

For causes of death that were considered chronic (eg, cancer, liver disease, cardiovascular disease), AAD and YPLL were estimated for decedents aged 20 years or older; for the majority of acute conditions, they were estimated for decedents aged 15 years or older. However, ARDI also estimates AAD and YPLL for chronic conditions for persons younger than 20 years who died from conditions attributable to drinking during pregnancy (eg, fetal alcohol spectrum disorders) and for acute conditions for persons younger than 15 years who died from motor-vehicle traffic crashes or child maltreatment. ARDI provides reports of AAD and YPLL by sex, age group, and state, and for those under age 21 years.

$\mathrm{AAD}$ and YPLL due to excessive alcohol use, including those among decedents under age 21 years, were obtained directly from the ARDI application. Average annual national and state rates for AAD and YPLL per 100,000 population from 2006 through 2010 were calculated by dividing the average annual AAD and YPLL estimates from ARDI for 2006 through 2010 by the average annual population estimates from the US Census for 2006-2010, and then multiplying by 100,000. The rates were then age-adjusted to the 2000 US population (11).

The proportion of total average annual deaths and YPLL among working-age adults that were alcohol-attributable was calculated by dividing the average annual AAD and YPLL estimates for adults aged 20 to 64 years from 2006 through 2010 from ARDI by the total average annual deaths and YPLL for all causes for adults aged 20 to 64 years from vital statistics, and then multiplying by 100.

\section{Results}

An average of 87,798 AAD and 2,560,290 YPLL occurred in the United States annually from 2006 through 2010 (Table 1). Overall, $44 \%$ of the AAD and $33 \%$ of the YPLL were due to chronic conditions, and $56 \%$ of the AAD and $67 \%$ of the YPLL were caused by acute conditions. Most AAD (71\%) and YPLL (72\%) involved males. The most common cause of chronic $\mathrm{AAD}$ was alcoholic liver disease, while the most common cause of acute AAD was motor-vehicle traffic crashes.

A total annual average of 4,358 AAD (5\%) and 249,727 YPLL (10\%) involved those under age 21 years from 2006 through 2010 (data not shown). Similar to the findings for adults, about $78 \%$ of the AAD and $76 \%$ of the YPLL in those younger than 21 involved males. However, in contrast to the findings for adults, all of the top 3 causes of death for those under age 21 years - specifically, motor-vehicle traffic crashes, homicide, and suicide -were acute conditions. In fact, motor-vehicle traffic crashes alone accounted for $36 \%$ of the total AAD for those under age 21 years.

The average annual age-adjusted AAD rate for the United States from 2006 through 2010 was 27.9 deaths per 100,000 population, with a range of 51.2 deaths per 100,000 (New Mexico) to 19.1 deaths per 100,000 (New Jersey) (Table 2). Twenty-six states and the District of Columbia (DC) had higher average annual age-adjusted AAD rates than the national rate, and 2 states (New Mexico and Alaska) reported average annual age-adjusted AAD rates above 40 deaths per 100,000 population. The average annual age-adjusted YPLL rate for the United States from 2006 through 2010 was 831.6 per 100,000 population, with a range of 1,570 YPLL per 100,000 (New Mexico) to 570 YPLL per 100,000 (Hawaii) (Table 3). The average annual age-adjusted YPLL rates in 23 states and the District of Columbia were higher than the national rate, and 12 states and DC reported over 1,000 YPLL per 100,000 population.

Average annual AAD were responsible for an average of $9.8 \%$ of total deaths (Table 2) and an average of $11.5 \%$ of YPLL among working-age adults (20-64 y) (Table 3) from 2006 through 2010.The average proportion of total deaths among working-age adults that were alcohol-attributable ranged from $16.4 \%$ in New Mexico to $7.5 \%$ in Maryland; the average proportion of total YPLL that were alcohol-attributable ranged from 18.5\% in New Mexico to 9.1\% in Maryland.

From 2006 through 2010 more than two-thirds (69\%) of all average annual AAD (Table 2) and 82\% of average annual YPLL (Table 3) involved working-age adults $(20-64 \mathrm{y})$. The proportion of average annual AAD in states that involved working-age adults ranged from $83 \%$ in Alaska to $56 \%$ in Vermont, and the proportion of average annual YPLL attributable to alcohol that involved working-age adults ranged from $88 \%$ in Alaska to $77 \%$ in Nebraska and Vermont.

\section{Discussion}


From 2006 through 2010, excessive alcohol consumption accounted for nearly 1 in 10 deaths and over 1 in 10 years of potential life lost among working-age adults in the United States. Furthermore, an average of 2 out of 3 AAD and 8 out of 10 alcohol-attributable YPLL involved working-age adults. Although AAD rates varied by state, the national annual average $\mathrm{AAD}$ rate of 27.9 deaths per 100,000 population was higher than the average annual death rate for 10 of the 15 leading causes of deaths from 2006 through 2010 (12). The majority of the average annual AAD involved males (71\%); over half of AAD and two-thirds of YPLL resulted from acute causes of death, all of which were by definition attributable to binge drinking. About $5 \%$ of all average annual AAD and $10 \%$ of average annual YPLL involved those under age 21 years, most of which were due to acute conditions.

The average annual estimates of AAD and YPLL for the United States from 2006 through 2010 are similar to the 2001 estimates (5) and emphasize the substantial and ongoing public health impact of excessive drinking in the United States. The differences in age-adjusted AAD and YPLL rates in states probably reflect differences in the prevalence of excessive drinking, particularly binge drinking, which is affected by state and local laws governing the price, availability, and marketing of alcoholic beverages (13). The differences in AAD and YPLL rates in states probably also reflect other factors, including access to medical care and vehicle miles traveled, which could affect the risk of death from alcohol-related conditions $(13,14)$. The higher rates of AAD and YPLL among men than women probably also reflects the higher prevalence, frequency, and intensity of binge drinking, the most common pattern of excessive alcohol consumption, among men (15).

The substantial contribution of excessive alcohol consumption to total deaths and premature mortality among working -age adults (20-64 y) in the United States, as well as the large proportion of these deaths (69\%) and YPLL (82\%) that involved working-age adults, is consistent with studies assessing the contribution of harmful alcohol consumption to the global burden of disease (16) and also reflects the substantial effect that excessive alcohol consumption has across the lifespan. The concentration of AAD and YPLL among working-age adults is also a major factor contributing to alcohol-attributable productivity losses from premature mortality, which, together with reduced earnings by excessive drinkers, was responsible for $72 \%$ of the estimated $\$ 223.5$ billion in economic costs from excessive alcohol consumption in 2006 (2).

The findings in this report are subject to several limitations. First, data on alcohol consumption used to calculate indirect estimates of AAF are based on self-reports and may underestimate the true prevalence of excessive alcohol consumption because of underreporting by survey respondents and sampling noncoverage (17). A recent study that used BRFSS data found that self-reports identify only $22 \%$ to $32 \%$ of presumed alcohol consumption in states on the basis of alcohol sales (18). Second, risk estimates used in ARDI were calculated by using average daily alcohol consumption levels that begin at levels greater than those typically used to define excessive drinking in the United States. Third, deaths among former drinkers, who might have discontinued their drinking because of alcohol-related health problems, are not included in the calculation of AAF, even though some of these deaths might have been alcohol -attributable. Fourth, ARDI does not include estimates of AAD for several causes (eg, tuberculosis, pneumonia, hepatitis C) for which alcohol is believed to be an important risk factor, but for which suitable pooled risk estimates were not available. Fifth, ARDI exclusively uses the underlying cause of death from vital statistics data to identify alcohol-related causes and does not consider contributing causes of death that might be alcohol-related. Finally, agespecific estimates of AAF were only available for motor-vehicle traffic deaths, even though alcohol involvement varies by age, particularly for acute causes of death. While our results do show the substantial burden of alcohol-related consequences, many of the limitations cited could result in a substantial underestimate of the true contribution of excessive alcohol consumption to total deaths and YPLL in the United States.

This analysis illustrates the magnitude and variability of the health consequences of excessive alcohol consumption in the United States, and the substantial contribution of excessive drinking to premature mortality among working-age adults. More widespread implementation of interventions recommended by the Community Preventive Services Task Force (19), including increasing alcohol prices by raising alcohol taxes, enforcing commercial host (dram shop) liability, and regulating alcohol outlet density, could reduce excessive alcohol consumption and the health and economic costs related to it.

\section{Acknowledgments}

This article is dedicated to Ron Davis, MD, MA, for his visionary leadership and commitment to the prevention of excessive alcohol use. We thank Henry Wechsler, PhD, retired, Harvard School of Public Health, Harvard University. The development of the ARDI application was supported by generous grants (nos. 044149 and 059738 ) from the Robert Wood Johnson Foundation to the CDC Foundation.

\section{Author Information}

Corresponding Author: Mandy Stahre, PhD, MPH, Epidemic Intelligence Service Officer, Washington State Department of Health, Olympia, WA 98504. Telephone: 360 236-4247. Email: mandy.stahre@doh.wa.gov. 
Author Affiliations: Jim Roeber, New Mexico Department of Health, Santa Fe, New Mexico; Dafna Kanny, Robert D. Brewer, Xingyou Zhang, Centers for Disease Control and Prevention, Atlanta, Georgia.

\section{References}

1. Mokdad AH, Marks JS, Stroup DF, Gerberding JL. Actual causes of death in the United States, 200o. [Published erratum in: JAMA 2005;293(3):293-4, 298]. JAMA 2004;291(10):1238-45. CrossRef 国 PubMed 圈

2. Bouchery EE, Harwood H, Sacks JJ, Simon CJ, Brewer RD. Economic costs of excessive alcohol consumption in the US, 2006. [Published erratum in: Am J Prev Med 2013;44(3):198]. Am J Prev Med 2011;41(5):516-24. CrossRef 圈 PubMed 圈

3. Centers for Disease Control and Prevention. Vital signs: binge drinking prevalence, frequency, and intensity among adults - United States, 2010. MMWR Morb Mortal Wkly Rep 2012;61(1):14-9. PubMed 圈

4. National Institutes of Health. 1oth Special Report to the US Congress on Alcohol and Health. Rockville (MD): US Department of Health and Human Services, National Institute on Alcohol Abuse and Alcoholism; 2000.

5. Centers for Disease Control and Prevention. Alcohol-attributable deaths and years of potential life lost - United States, 2001. MMWR Morb Mortal Wkly Rep 2004;53(37):866-70. PubMed 圈

6. Centers for Disease Control and Prevention. Alcohol Related Disease Impact (ARDI) application, 2013. http://apps.nccd.cdc.gov/DACH_ARDI/Default.aspx. Accessed April 3, 2013.

7. English DR, Holman CDJ, Milne E, Winter MG, Hulse GK, Codde JP, et al. The quantification of drug caused morbidity and mortality in Australia. 1995 edition. Canberra (AU): Commonwealth Department of Human Services and Health; 1995.

8. Corrao G, Bargnardi V, Zambon A, Arico S. Exploring the dose-response relationship between alcohol consumption and the risk of several alcohol-related conditions: a meta-analysis. Addiction 1999;94(10):1551-73. CrossRef 圈 PubMed 国

9. Centers for Disease Control and Prevention. Behavioral Risk Factor Surveillance System. http://www.cdc.gov/brfss. Accessed April 1, 2013.

10. Smith GS, Branas CS, Miller TR. Fatal nontraffic injuries involving alcohol: a meta-analysis. Ann Emerg Med 1999;33(6):659-68. PubMed 圈

11. Klein RJ, Schoenborn CA. Age adjustment using the 2000 projected US population. Statistical Notes. No. 20. Hyattsville (MD): National Center for Health Statistics; 2001.

12. Murphy SL, Xu JQ, Kochanek KD. Deaths: final data for 2010. National Vital Statistics Reports; Vol 61 no 4. Hyattsville (MD): National Center for Health Statistics; 2013.

13. Naimi TS, Blanchette J, Nelson TF, Nguyen T, Oussayef N, Heeren TC, et al. A new scale of the US alcohol policy environment and its relationship to binge drinking. Am J Prev Med 2014;46(1):10-6. CrossRef 国 PubMed 国

14. Branas CC, MacKenzie EJ, Williams JC, Schwab CW, Teter HM, Flanigan MC, et al. Access to trauma centers in the United States. JAMA 2005;293(21):2626-33. CrossRef 圈 PubMed 圈

15. Kanny D, Liu Y, Brewer RD, Lu H. Binge drinking - United States, 2011. MMWR Surveill Summ 2013;62(Suppl 3):77-80. PubMed 娄

16. Rehm J, Mathers C, Popova S, Thavorncharoensap M, Teerawattananon Y, Patra J. Global burden of disease and injury and economic cost attributable to alcohol use and alcohol-use disorders. Lancet 2009;373(9682):2223-33. CrossRef 圈 PubMed 圈

17. Stockwell T, Donath S, Cooper-Stanbury M, Chikritzhs TN, Catalano P, Mateo C. Under-reporting of alcohol consumption in household surveys: a comparison of quantity-frequency, graduate-frequency and recent recall. Addiction 2004;99(8):1024-33. CrossRef 国 PubMed 圈

18. Nelson DE, Naimi TS, Brewer RD, Roeber JUS. State alcohol sales compared to survey data, 1993-2006. Addiction 2010;105(9):1589-96. CrossRef 圈 PubMed 圈

19. Community Preventive Services Task Force. Preventing excessive alcohol consumption. In: The guide to community preventive services. New York, NY: Oxford University Press; 2005. http://www.thecommunityguide.org/alcohol/index.html. Accessed April 3, 2014.

\section{Tables}


Preventing Chronic Disease | Contribution of Excessive Alcohol Consumption to Deaths ... Page 6 of 12

Table 1. Average Annual Number of Deaths and Years of Potential Life Lost (YPLL) Attributable to the Harmful Effects of Excessive Alcohol Use, by Cause and Sex, United States, 2006-2010

\begin{tabular}{|c|c|c|c|c|c|c|}
\hline \multirow[b]{2}{*}{ Cause } & \multicolumn{3}{|c|}{ Deaths } & \multicolumn{3}{|c|}{ YPLL } \\
\hline & $\begin{array}{l}\text { Male, } n \\
(\%)\end{array}$ & $\begin{array}{l}\text { Female, } n \\
(\%)\end{array}$ & Total & Male, n (\%) & $\begin{array}{l}\text { Female, } n \\
(\%)\end{array}$ & Total \\
\hline \multicolumn{7}{|l|}{ Chronic causes } \\
\hline Acute pancreatitis & $411(57)$ & $313(43)$ & 724 & $8,459(62)$ & $5,263(38)$ & 13,722 \\
\hline Alcohol abuse & $\begin{array}{r}1,587 \\
(78)\end{array}$ & $435(22)$ & 2,022 & $39,949(76)$ & $12,842(24)$ & 52,791 \\
\hline Alcohol cardiomyopathy & $441(86)$ & $73(14)$ & 514 & $10,357(84)$ & $1,909(16)$ & 12,266 \\
\hline Alcohol dependence syndrome & $\begin{array}{r}2,892 \\
(78)\end{array}$ & $836(22)$ & 3,728 & $72,208(75)$ & $24,099(25)$ & 96,307 \\
\hline Alcohol polyneuropathy & $7(100)$ & 0 & 7 & $117(100)$ & 0 & 117 \\
\hline Alcohol-induced chronic pancreatitis & $59(72)$ & $23(28)$ & 82 & $1,546(70)$ & $673(30)$ & 2,219 \\
\hline Alcoholic gastritis & $23(79)$ & $6(21)$ & 29 & $586(75)$ & $191(25)$ & 777 \\
\hline Alcoholic liver disease & $\begin{array}{r}10,403 \\
(72)\end{array}$ & $3,961(28)$ & 14,364 & $251,921(69)$ & $\begin{array}{r}114,347 \\
(31)\end{array}$ & 366,268 \\
\hline Alcoholic myopathy & $1(100)$ & 0 & 1 & $23(100)$ & 0 & 23 \\
\hline Alcoholic psychosis & $502(77)$ & $151(23)$ & 653 & $10,511(76)$ & $3,294(24)$ & 13,805 \\
\hline Breast cancer (female only) & NA & $391(100)$ & 391 & NA & $7,429(100)$ & 7,429 \\
\hline Cholelithiases & 0 & 0 & 0 & 0 & 0 & 0 \\
\hline Chronic hepatitis & $1(100)$ & $<1$ & 1 & $20(71)$ & $8(29)$ & 28 \\
\hline Chronic pancreatitis & $139(55)$ & $116(45)$ & 255 & $2,940(56)$ & $2,297(44)$ & 5,237 \\
\hline $\begin{array}{l}\text { Degeneration of nervous system due to } \\
\text { alcohol }\end{array}$ & $104(83)$ & $22(17)$ & 126 & $1,804(79)$ & $477(21)$ & 2,281 \\
\hline Epilepsy & $108(53)$ & $95(47)$ & 203 & $3,170(55)$ & $2,612(45)$ & 5,783 \\
\hline Esophageal cancer & $437(89)$ & $55(11)$ & 492 & $6,957(89)$ & $848(11)$ & 7,805 \\
\hline Esophageal varices & $47(72)$ & $18(28)$ & 65 & $1,032(72)$ & $397(28)$ & 1,430 \\
\hline Fetal alcohol syndrome & $3(75)$ & $1(25)$ & 4 & $163(68)$ & $78(32)$ & 241 \\
\hline $\begin{array}{l}\text { Fetus and newborn affected by maternal } \\
\text { use of alcohol }\end{array}$ & $1(50)$ & $1(50)$ & 2 & $75(48)$ & $80(52)$ & 155 \\
\hline Gastro-esophageal hemorrhage & $19(61)$ & $12(39)$ & 31 & $332(66)$ & $173(34)$ & 505 \\
\hline Hypertension & $874(55)$ & $729(45)$ & 1,603 & $13,684(61)$ & 8,737 (39) & 22,421 \\
\hline Ischemic heart disease & $516(70)$ & $223(30)$ & 738 & $6,745(73)$ & $2,434(27)$ & 9,178 \\
\hline Laryngeal cancer & $198(86)$ & $33(14)$ & 231 & $3,126(84)$ & $581(16)$ & 3,707 \\
\hline Liver cancer & $752(75)$ & $245(25)$ & 997 & $13,033(77)$ & $3,893(23)$ & 16,926 \\
\hline Liver cirrhosis, unspecified & $\begin{array}{r}4,592 \\
(59)\end{array}$ & $3,255(41)$ & 7,847 & $93,308(59)$ & $64,114(41)$ & 157,422 \\
\hline $\begin{array}{l}\text { Low birth weight, prematurity, } \\
\text { intrauterine growth restriction death }\end{array}$ & $106(64)$ & $60(36)$ & 165 & $7,915(62)$ & $4,790(38)$ & 12,705 \\
\hline Oropharyngeal cancer & $309(85)$ & $56(15)$ & 365 & $5,401(86)$ & $912(14)$ & 6,313 \\
\hline Portal hypertension & $24(63)$ & $14(37)$ & 38 & $511(66)$ & $261(34)$ & 772 \\
\hline Prostate cancer & $202(100)$ & NA & 202 & $1,985(100)$ & NA & 1,985 \\
\hline
\end{tabular}




\begin{tabular}{|c|c|c|c|c|c|c|}
\hline \multirow[b]{2}{*}{ Cause } & \multicolumn{3}{|c|}{ Deaths } & \multicolumn{3}{|c|}{ YPLL } \\
\hline & $\begin{array}{l}\text { Male, n } \\
(\%)\end{array}$ & $\begin{array}{c}\text { Female, } n \\
(\%)\end{array}$ & Total & Male, n (\%) & $\begin{array}{c}\text { Female, } n \\
(\%)\end{array}$ & Total \\
\hline Psoriasis & $<1$ & $<1$ & $<1$ & $2(67)$ & $1(33)$ & 3 \\
\hline Spontaneous abortion & $N A$ & $<1$ & $<1$ & $N A$ & $10(100)$ & 10 \\
\hline Stroke, hemorrhagic & $\begin{array}{r}1,357 \\
(83)\end{array}$ & $286(17)$ & 1,643 & $21,292(83)$ & $4,389(17)$ & 25,681 \\
\hline Stroke, ischemic & $329(74)$ & $118(26)$ & 447 & $3,812(76)$ & $1,227(24)$ & 5,039 \\
\hline Superventricular cardiac dysrhythymia & $122(43)$ & $160(57)$ & 282 & $1,065(44)$ & $1,356(56)$ & 2,421 \\
\hline Subtotal & $\begin{array}{r}26,564 \\
(69) \\
\end{array}$ & $\begin{array}{r}11,689 \\
(31)\end{array}$ & 38,253 & $\begin{array}{r}584,050 \\
(68) \\
\end{array}$ & $\begin{array}{r}269,722 \\
(32) \\
\end{array}$ & 853,771 \\
\hline \multicolumn{7}{|l|}{ Acute causes } \\
\hline Air-space transport & $81(84)$ & $15(16)$ & 96 & $2,408(81)$ & $569(19)$ & 2,977 \\
\hline Alcohol poisoning & $\begin{array}{r}1,264 \\
(77) \\
\end{array}$ & $383(23)$ & 1,647 & $42,299(75)$ & $13,833(25)$ & 56,132 \\
\hline Aspiration & $125(57)$ & $94(43)$ & 220 & $2,431(59)$ & $1,701(41)$ & 4,132 \\
\hline Child maltreatment & $98(59)$ & $70(42)$ & 167 & $6,947(57)$ & $5,345(43)$ & 12,292 \\
\hline Drowning & $770(80)$ & $193(20)$ & 963 & $27,802(82)$ & $6,194(18)$ & 33,997 \\
\hline Excessive blood alcohol level & 0 & 0 & 0 & 0 & 0 & 0 \\
\hline Fall injuries & $\begin{array}{r}3,853 \\
(51) \\
\end{array}$ & $3,688(49)$ & 7,541 & $53,443(58)$ & $39,015(42)$ & 92,458 \\
\hline Fire injuries & $645(59)$ & $444(41)$ & 1,089 & $15,914(59)$ & $11,014(41)$ & 26,928 \\
\hline Firearm injuries & $86(88)$ & $12(12)$ & 98 & $3,337(87)$ & $481(13)$ & 3,817 \\
\hline Homicide & $\begin{array}{r}6,221 \\
(80) \\
\end{array}$ & $1,535(20)$ & 7,756 & $274,753(81)$ & $64,612(19)$ & 339,364 \\
\hline Hypothermia & $177(67)$ & $88(33)$ & 265 & $4,114(72)$ & $1,585(28)$ & 5,699 \\
\hline Motor-vehicle nontraffic crashes & $171(78)$ & $49(22)$ & 220 & $5,345(77)$ & $1,554(23)$ & 6,899 \\
\hline Motor-vehicle traffic crashes & $\begin{array}{r}9,764 \\
(78) \\
\end{array}$ & $2,696(22)$ & 12,460 & $398,376(77)$ & $\begin{array}{r}121,314 \\
(23) \\
\end{array}$ & 519,690 \\
\hline Occupational and machine injuries & $126(94)$ & $8(6)$ & 134 & $3,359(94)$ & $201(6)$ & 3,560 \\
\hline Other road vehicle crashes & $146(79)$ & $38(21)$ & 184 & $4,857(78)$ & $1,363(22)$ & 6,220 \\
\hline Poisoning (not alcohol) & $\begin{array}{r}5,457 \\
(65) \\
\end{array}$ & $2,947(35)$ & 8,404 & $203,635(65)$ & $\begin{array}{r}111,371 \\
(35) \\
\end{array}$ & 315,007 \\
\hline Suicide & $\begin{array}{r}6,460 \\
(79) \\
\end{array}$ & $1,719(21)$ & 8,179 & $210,811(77)$ & $62,395(23)$ & 273,206 \\
\hline Suicide by and exposure to alcohol & $28(67)$ & $14(33)$ & 42 & $842(62)$ & $524(38)$ & 1,366 \\
\hline Water transport & $69(87)$ & $10(13)$ & 79 & $2,349(85)$ & $427(15)$ & 2,776 \\
\hline Subtotal & $\begin{array}{r}35,540 \\
(72) \\
\end{array}$ & $\begin{array}{r}14,004 \\
(28) \\
\end{array}$ & 49,544 & $\begin{array}{r}1,263,023 \\
(74) \\
\end{array}$ & $\begin{array}{r}443,497 \\
(26) \\
\end{array}$ & $1,706,519$ \\
\hline Total & $\begin{array}{r}62,104 \\
(71)\end{array}$ & $\begin{array}{r}25,693 \\
(29)\end{array}$ & 87,798 & $\begin{array}{r}1,847,072 \\
(72)\end{array}$ & $\begin{array}{r}713,218 \\
(28)\end{array}$ & $2,560,290$ \\
\hline
\end{tabular}

Abbreviation: NA, not applicable. 
Preventing Chronic Disease | Contribution of Excessive Alcohol Consumption to Deaths ... Page 8 of 12

Table 2. Average Annual Number of Deaths and Alcohol-Attributable Deaths (AAD), and Percentage of Deaths Among All Ages and Among Persons Aged 20-64 years, by State, United States, 2006-2010.

\begin{tabular}{|c|c|c|c|c|c|c|c|}
\hline \multirow[b]{2}{*}{ State } & \multicolumn{4}{|c|}{ All Ages } & \multicolumn{3}{|c|}{ 20-64 years } \\
\hline & $\begin{array}{c}\text { Total } \\
\text { Deaths }\end{array}$ & $\begin{array}{l}\text { Total } \\
\text { AAD }\end{array}$ & $\begin{array}{c}\text { Age-Adjusted } \\
\text { AAD Rate per } \\
100,000\end{array}$ & $\begin{array}{c}\text { Total Alcohol- } \\
\text { Attributable } \\
\text { Deaths, \% }\end{array}$ & $\begin{array}{c}\text { Total } \\
\text { Deaths }\end{array}$ & $\begin{array}{l}\text { Total } \\
\text { AAD }\end{array}$ & $\begin{array}{c}\text { Total Alcohol- } \\
\text { Attributable } \\
\text { Deaths, } \\
\%\end{array}$ \\
\hline $\begin{array}{l}\text { United States, } \\
\text { total }\end{array}$ & $2,445,322$ & 87,798 & 27.9 & 3.6 & 620,259 & 60,617 & 9.8 \\
\hline Alabama & 47,377 & 1,511 & 31.0 & 3.2 & 13,688 & 1,119 & 8.2 \\
\hline Alaska & 3,531 & 275 & 41.1 & 7.8 & 1,443 & 229 & 15.9 \\
\hline Arizona & 46,023 & 2,362 & 37.2 & 5.1 & 12,178 & 1,626 & 13.4 \\
\hline Arkansas & 28,600 & 920 & 31.0 & 3.2 & 7,874 & 650 & 8.3 \\
\hline California & 234,436 & 10,572 & 29.1 & 4.5 & 60,612 & 7,476 & 12.3 \\
\hline Colorado & 30,684 & 1,628 & 33.2 & 5.3 & 8,429 & 1,200 & 14.2 \\
\hline Connecticut & 28,794 & 836 & 22.1 & 2.9 & 5,904 & 544 & 9.2 \\
\hline Delaware & 7,477 & 248 & 26.8 & 3.3 & 1,958 & 172 & 8.8 \\
\hline $\begin{array}{l}\text { District of } \\
\text { Columbia }\end{array}$ & 5,035 & 210 & 34.7 & 4.2 & 1,732 & 155 & 9.0 \\
\hline Florida & 170,507 & 6,643 & 32.6 & 3.9 & 40,970 & 4,493 & 11.0 \\
\hline Georgia & 69,347 & 2,555 & 27.6 & 3.7 & 21,580 & 1,854 & 8.6 \\
\hline Hawaii & 9,591 & 304 & 20.8 & 3.2 & 2,355 & 191 & 8.1 \\
\hline Idaho & 10,985 & 437 & 28.9 & 4.0 & 2,578 & 291 & 11.3 \\
\hline Illinois & 101,218 & 3,042 & 23.4 & 3.0 & 24,479 & 2,067 & 8.4 \\
\hline Indiana & 55,816 & 1,646 & 25.1 & 2.9 & 14,102 & 1,168 & 8.3 \\
\hline Iowa & 27,682 & 775 & 23.8 & 2.8 & 5,322 & 459 & 8.6 \\
\hline Kansas & 24,508 & 762 & 26.6 & 3.1 & 5,453 & 518 & 9.5 \\
\hline Kentucky & 40,976 & 1,351 & 30.5 & 3.3 & 11,518 & 994 & 8.6 \\
\hline Louisiana & 40,433 & 1,475 & 32.8 & 3.6 & 12,495 & 1,103 & 8.8 \\
\hline Maine & 12,534 & 372 & 24.8 & 3.0 & 2,722 & 241 & 8.9 \\
\hline Maryland & 43,677 & 1,318 & 22.6 & 3.0 & 11,928 & 899 & 7.5 \\
\hline Massachusetts & 52,954 & 1,525 & 21.8 & 2.9 & 10,920 & 1,022 & 9.4 \\
\hline Michigan & 87,136 & 2,945 & 28.1 & 3.4 & 21,977 & 2,020 & 9.2 \\
\hline Minnesota & 37,897 & 1,257 & 23.3 & 3.3 & 7,896 & 778 & 9.9 \\
\hline Mississippi & 28,603 & 1,025 & 34.8 & 3.6 & 8,711 & 755 & 8.7 \\
\hline Missouri & 54,990 & 1,866 & 30.3 & 3.4 & 13,661 & 1,256 & 9.2 \\
\hline Montana & 8,713 & 390 & 37.7 & 4.5 & 2,090 & 275 & 13.2 \\
\hline Nebraska & 15,121 & 422 & 22.7 & 2.8 & 3,040 & 261 & 8.6 \\
\hline Nevada & 19,147 & 943 & 34.9 & 4.9 & 5,979 & 694 & 11.6 \\
\hline $\begin{array}{l}\text { New } \\
\text { Hampshire }\end{array}$ & 10,186 & 341 & 23.8 & 3.3 & 2,289 & 222 & 9.7 \\
\hline New Jersey & 69,557 & 1,754 & 19.1 & 2.5 & 15,543 & 1,206 & 7.8 \\
\hline
\end{tabular}




\begin{tabular}{|c|c|c|c|c|c|c|c|}
\hline \multirow[b]{2}{*}{ State } & \multicolumn{4}{|c|}{ All Ages } & \multicolumn{3}{|c|}{$20-64$ years } \\
\hline & $\begin{array}{c}\text { Total } \\
\text { Deaths }\end{array}$ & $\begin{array}{l}\text { Total } \\
\text { AAD }\end{array}$ & $\begin{array}{c}\text { Age-Adjusted } \\
\text { AAD Rate per } \\
100,000\end{array}$ & $\begin{array}{c}\text { Total Alcohol- } \\
\text { Attributable } \\
\text { Deaths, \% }\end{array}$ & $\begin{array}{c}\text { Total } \\
\text { Deaths }\end{array}$ & $\begin{array}{l}\text { Total } \\
\text { AAD }\end{array}$ & $\begin{array}{c}\text { Total Alcohol- } \\
\text { Attributable } \\
\text { Deaths, } \\
\%\end{array}$ \\
\hline New Mexico & 15,670 & 1,042 & 51.2 & 6.6 & 4,619 & 758 & 16.4 \\
\hline New York & 147,610 & 4,011 & 19.6 & 2.7 & 33,826 & 2,659 & 7.9 \\
\hline North Carolina & 76,780 & 2,761 & 28.9 & 3.6 & 20,949 & 1,947 & 9.3 \\
\hline North Dakota & 5,832 & 179 & 26.2 & 3.1 & 1,123 & 115 & 10.2 \\
\hline Ohio & 107,798 & 3,288 & 26.9 & 3.1 & 25,994 & 2,179 & 8.4 \\
\hline Oklahoma & 36,120 & 1,350 & 35.9 & 3.7 & 9,974 & 1,000 & 10.0 \\
\hline Oregon & 31,655 & 1,302 & 32.1 & 4.1 & 7,456 & 863 & 11.6 \\
\hline Pennsylvania & 125,482 & 3,510 & 25.8 & 2.8 & 26,807 & 2,290 & 8.5 \\
\hline Rhode Island & 9,625 & 292 & 25.3 & 3.0 & 1,948 & 188 & 9.7 \\
\hline South Carolina & 40,107 & 1,534 & 32.6 & 3.8 & 11,995 & 1,133 & 9.4 \\
\hline South Dakota & 7,003 & 249 & 30.0 & 3.6 & 1,431 & 158 & 11.0 \\
\hline Tennessee & 58,120 & 2,064 & 31.8 & 3.6 & 16,891 & 1,511 & 8.9 \\
\hline Texas & 162,469 & 6,514 & 27.9 & 4.0 & 47,458 & 4,660 & 9.8 \\
\hline Utah & 14,171 & 529 & 22.9 & 3.7 & 3,751 & 393 & 10.5 \\
\hline Vermont & 5,170 & 183 & 26.5 & 3.5 & 1,125 & 103 & 9.2 \\
\hline Virginia & 58,536 & 1,865 & 23.1 & 3.2 & 15,193 & 1,292 & 8.5 \\
\hline Washington & 47,696 & 1,981 & 29.2 & 4.2 & 11,702 & 1,301 & 11.1 \\
\hline West Virginia & 21,195 & 660 & 33.1 & 3.1 & 5,540 & 468 & 8.4 \\
\hline Wisconsin & 46,442 & 1,706 & 28.5 & 3.7 & 9,866 & 1,027 & 10.4 \\
\hline Wyoming & 4,305 & 210 & 37.5 & 4.9 & 1,188 & 159 & 13.4 \\
\hline
\end{tabular}

Table 3. Average Annual Number of Years of Potential Life Lost (YPLL), Total YPLL, and Percentage of YPLL Among All Ages and Among Persons Aged 20 to 64 Years, by State, United States, 2006-2010

\begin{tabular}{|c|c|c|c|c|c|c|c|}
\hline \multirow[b]{2}{*}{ State } & \multicolumn{4}{|c|}{ All Ages } & \multicolumn{3}{|c|}{$20-64$ years } \\
\hline & $\begin{array}{l}\text { Total } \\
\text { YPLL }\end{array}$ & $\begin{array}{l}\text { Total Alcohol } \\
\text {-Attributable } \\
\text { YPLL }\end{array}$ & $\begin{array}{c}\text { Age- } \\
\text { Adjusted } \\
\text { YPLL Rate } \\
\text { per } \\
100,000\end{array}$ & $\begin{array}{l}\text { Total Alcohol } \\
\text {-Attributable } \\
\text { YPLL, \% }\end{array}$ & $\begin{array}{l}\text { Total } \\
\text { YPLL }\end{array}$ & $\begin{array}{l}\text { Total Alcohol } \\
\text {-Attributable } \\
\text { YPLL }\end{array}$ & $\begin{array}{l}\text { Total Alcohol } \\
\text {-Attributable } \\
\text { YPLL, \% }\end{array}$ \\
\hline $\begin{array}{l}\text { United States, } \\
\text { total }\end{array}$ & $38,281,133$ & $2,560,290$ & 831.6 & 6.7 & $18,380,927$ & $2,106,126$ & 11.5 \\
\hline Alabama & 797,361 & 48,424 & 1030.1 & 6.1 & 408,573 & 40,535 & 9.9 \\
\hline Alaska & 75,697 & 9,131 & 1299.6 & 12.1 & 45,281 & 8,042 & 17.8 \\
\hline Arizona & 757,615 & 68,826 & 1111.8 & 9.1 & 368,170 & 56,603 & 15.4 \\
\hline Arkansas & 469,241 & 28,226 & 991.3 & 6.0 & 234,355 & 23,211 & 9.9 \\
\hline California & $3,704,628$ & 304,472 & 822.0 & 8.2 & $1,806,358$ & 251,821 & 13.9 \\
\hline Colorado & 506,006 & 47,269 & 942.8 & 9.3 & 254,887 & 40,451 & 15.9 \\
\hline Connecticut & 398,287 & 23,149 & 646.4 & 5.8 & 173,316 & 18,988 & 11.0 \\
\hline
\end{tabular}




\begin{tabular}{|c|c|c|c|c|c|c|c|}
\hline \multirow[b]{2}{*}{ State } & \multicolumn{4}{|c|}{ All Ages } & \multicolumn{3}{|c|}{$20-64$ years } \\
\hline & $\begin{array}{l}\text { Total } \\
\text { YPLL }\end{array}$ & $\begin{array}{c}\text { Total Alcohol } \\
\text {-Attributable } \\
\text { YPLL }\end{array}$ & \begin{tabular}{|c|} 
Age- \\
Adjusted \\
YPLL Rate \\
per \\
100,000
\end{tabular} & $\begin{array}{c}\text { Total Alcohol } \\
\text {-Attributable } \\
\text { YPLL, \% }\end{array}$ & $\begin{array}{l}\text { Total } \\
\text { YPLL }\end{array}$ & $\begin{array}{c}\text { Total Alcohol } \\
\text {-Attributable } \\
\text { YPLL }\end{array}$ & $\begin{array}{l}\text { Total Alcohol } \\
\text {-Attributable } \\
\text { YPLL, \% }\end{array}$ \\
\hline Delaware & 119,510 & 7,453 & 840.5 & 6.2 & 58,397 & 6,079 & 10.4 \\
\hline $\begin{array}{l}\text { District of } \\
\text { Columbia }\end{array}$ & 93,741 & 6,725 & 1083.9 & 7.2 & 52,568 & 5,426 & 10.3 \\
\hline Florida & $2,580,471$ & 187,068 & 999.6 & 7.2 & $1,217,429$ & 154,447 & 12.7 \\
\hline Georgia & $1,227,003$ & 79,183 & 829.1 & 6.5 & 645,519 & 65,864 & 10.2 \\
\hline Hawaii & 145,318 & 7,915 & 569.7 & 5.4 & 68,676 & 6,335 & 9.2 \\
\hline Idaho & 171,134 & 12,311 & 819.7 & 7.2 & 76,901 & 9,873 & 12.8 \\
\hline Illinois & $1,557,893$ & 91,615 & 711.8 & 5.9 & 723,596 & 73,823 & 10.2 \\
\hline Indiana & 879,690 & 50,042 & 780.9 & 5.7 & 416,119 & 41,253 & 9.9 \\
\hline Iowa & 375,846 & 19,885 & 654.8 & 5.3 & 153,969 & 15,498 & 10.1 \\
\hline Kansas & 364,862 & 22,131 & 792.1 & 6.1 & 161,373 & 18,091 & 11.2 \\
\hline Kentucky & 672,103 & 41,780 & 969.0 & 6.2 & 341,312 & 35,393 & 10.4 \\
\hline Louisiana & 715,228 & 49,719 & 1116.6 & 7.0 & 379,576 & 41,270 & 10.9 \\
\hline Maine & 176,731 & 9,929 & 723.2 & 5.6 & 77,630 & 8,064 & 10.4 \\
\hline Maryland & 713,579 & 40,075 & 694.8 & 5.6 & 357,601 & 32,410 & 9.1 \\
\hline Massachusetts & 728,381 & 41,501 & 616.0 & 5.7 & 318,262 & 34,389 & 10.8 \\
\hline Michigan & $1,343,335$ & 84,215 & 838.0 & 6.3 & 644,275 & 68,738 & 10.7 \\
\hline Minnesota & 537,350 & 32,829 & 616.2 & 6.1 & 231,357 & 26,237 & 11.3 \\
\hline Mississippi & 504,546 & 32,916 & 1134.4 & 6.5 & 261,516 & 27,550 & 10.5 \\
\hline Missouri & 856,379 & 55,681 & 941.2 & 6.5 & 405,162 & 44,787 & 11.1 \\
\hline Montana & 133,084 & 11,331 & 1163.5 & 8.5 & 62,408 & 9,471 & 15.2 \\
\hline Nebraska & 214,124 & 11,682 & 651.0 & 5.5 & 88,984 & 9,037 & 10.2 \\
\hline Nevada & 334,423 & 27,923 & 1034.9 & 8.3 & 177,069 & 23,441 & 13.2 \\
\hline $\begin{array}{l}\text { New } \\
\text { Hampshire }\end{array}$ & 145,490 & 8,789 & 637.1 & 6.0 & 66,054 & 7,260 & 11.0 \\
\hline New Jersey & $1,005,669$ & 50,856 & 575.8 & 5.1 & 457,224 & 42,068 & 9.2 \\
\hline New Mexico & 268,778 & 31,129 & 1570.1 & 11.6 & 142,364 & 26,281 & 18.5 \\
\hline New York & $2,162,819$ & 111,986 & 564.5 & 5.2 & 985,558 & 90,878 & 9.2 \\
\hline North Carolina & $1,259,703$ & 83,125 & 886.8 & 6.6 & 619,963 & 68,842 & 11.1 \\
\hline North Dakota & 81,298 & 5,132 & 785.5 & 6.3 & 33,320 & 4,061 & 12.2 \\
\hline Ohio & $1,632,999$ & 91,851 & 789.8 & 5.6 & 757,943 & 74,828 & 9.9 \\
\hline Oklahoma & 595,524 & 41,460 & 1134.1 & 7.0 & 295,639 & 34,833 & 11.8 \\
\hline Oregon & 462,860 & 33,933 & 868.3 & 7.3 & 215,541 & 27,934 & 13.0 \\
\hline Pennsylvania & $1,789,327$ & 100,106 & 794.0 & 5.6 & 785,357 & 81,180 & 10.3 \\
\hline Rhode Island & 131,293 & 7,538 & 687.4 & 5.7 & 56,371 & 6,178 & 11.0 \\
\hline South Carolina & 680,320 & 47,267 & 1037.5 & 6.9 & 353,461 & 39,646 & 11.2 \\
\hline South Dakota & 101,838 & 7,023 & 889.3 & 6.9 & 42,598 & 5,519 & 13.0 \\
\hline
\end{tabular}




\begin{tabular}{|c|c|c|c|c|c|c|c|}
\hline \multirow[b]{2}{*}{ State } & \multicolumn{4}{|c|}{ All Ages } & \multicolumn{3}{|c|}{ 20-64 years } \\
\hline & $\begin{array}{l}\text { Total } \\
\text { YPLL }\end{array}$ & $\begin{array}{c}\text { Total Alcohol } \\
\text {-Attributable } \\
\text { YPLL }\end{array}$ & $\begin{array}{c}\text { Age- } \\
\text { Adjusted } \\
\text { YPLL Rate } \\
\text { per } \\
100,000\end{array}$ & $\begin{array}{c}\text { Total Alcohol } \\
\text {-Attributable } \\
\text { YPLL, \% }\end{array}$ & $\begin{array}{l}\text { Total } \\
\text { YPLL }\end{array}$ & $\begin{array}{c}\text { Total Alcohol } \\
\text {-Attributable } \\
\text { YPLL }\end{array}$ & $\begin{array}{l}\text { Total Alcohol } \\
\text {-Attributable } \\
\text { YPLL, \% }\end{array}$ \\
\hline Tennessee & 972,290 & 63,058 & 999.8 & 6.5 & 500,315 & 52,831 & 10.6 \\
\hline Texas & $2,799,886$ & 199,618 & 823.6 & 7.1 & $1,429,308$ & 165,170 & 11.6 \\
\hline Utah & 245,204 & 16,800 & 673.9 & 6.9 & 119,423 & 14,075 & 11.8 \\
\hline Vermont & 72,760 & 4,335 & 664.6 & 6.0 & 32,292 & 3,317 & 10.3 \\
\hline Virginia & 931,966 & 55,232 & 687.3 & 5.9 & 447,064 & 45,349 & 10.1 \\
\hline Washington & 719,348 & 53,050 & 784.1 & 7.4 & 342,548 & 43,400 & 12.7 \\
\hline West Virginia & 330,370 & 19,464 & 1056.6 & 5.9 & 162,457 & 16,477 & 10.1 \\
\hline Wisconsin & 665,699 & 44,249 & 769.0 & 6.6 & 289,133 & 34,776 & 12.0 \\
\hline Wyoming & 72,123 & 6,480 & 1183.3 & 9.0 & 36,352 & 5,563 & 15.3 \\
\hline
\end{tabular}

\section{Post-Test Information}

To obtain credit, you should first read the journal article. After reading the article, you should be able to answer the following, related, multiple-choice questions. To complete the questions (with a minimum $75 \%$ passing score) and earn continuing medical education (CME) credit, please go to http://www.medscape.org/journal/pcd 圈. Credit cannot be obtained for tests completed on paper, although you may use the worksheet below to keep a record of your answers. You must be a registered user on Medscape.org. If you are not registered on Medscape.org, please click on the "Register" link on the right hand side of the website to register. Only one answer is correct for each question. Once you successfully answer all post-test questions you will be able to view and/or print your certificate. For questions regarding the content of this activity, contact the accredited provider,CME@medscape.net. For technical assistance, contact CME@webmd.net. American Medical Association's Physician's Recognition Award (AMA PRA) credits are accepted in the US as evidence of participation in CME activities. For further information on this award, please refer tohttp://www.ama-assn.org/ama/pub/about-ama/awards/ama-physicians-recognition-award.page 圈 . The AMA has determined that physicians not licensed in the US who participate in this CME activity are eligible for $\boldsymbol{A M A} \boldsymbol{P R A}$ Category 1 Credits $^{\mathrm{TM}}$. Through agreements that the AMA has made with agencies in some countries, AMA PRA credit may be acceptable as evidence of participation in CME activities. If you are not licensed in the US, please complete the questions online, print the AMA PRA CME credit certificate and present it to your national medical association for review.

\section{Post-Test Questions}

\section{Article Title: Contribution of Excessive Alcohol Consumption to Deaths and Years of Potential Life Lost in the United States}

\section{CME Questions}

1. You are seeing a 30-year-old woman who reports a history of binge drinking several times per month as well as past heavy drinking. You express your concern over her drinking, but you are unsure which problem drinking pattern is most harmful. Overall, which of the following forms of problem drinking account for the highest proportion of deaths from excessive alcohol use?
A. Heavy weekly alcohol consumption
B. Cumulative heavy drinking during a period of at least 5 years
C. Binge drinking
D. Drinking during pregnancy

2. What should you consider regarding the epidemiology of alcohol-attributable deaths and years of potential life lost in the current study by Stahre and colleagues?
A. The gross numbers of alcohol-attributable deaths and years of potential life lost failed to decrease since the last measurement in 2001
B. Approximately $30 \%$ of alcohol-attributable deaths occurred among individuals younger than 21 years
C. Alcohol-attributable deaths and years of potential life lost affected men and women equally 
D. Older adults ( $>65$ years) accounted for most cases of alcohol-attributable deaths and years of potential life lost

3. Which of the following states had the highest rates of alcohol-attributable deaths and years of potential life lost in the current study by Stahre and colleagues?
A. Delaware
B. New York
C. New Mexico
D. Alabama

4. According to the current study by Stahre and colleagues, what percentage of all deaths was caused by excessive alcohol use between 2006 and 2010?
A. $0.4 \%$
B. $2 \%$
C. $3 \%$
D. $10 \%$

\section{Evaluation}

1. The activity supported the learning objectives.

Strongly Disagree

1

2

3

2. The material was organized clearly for learning to occur.

Strongly Disagree

1

2

3

4

Strongly Agree

5

3. The content learned from this activity will impact my practice.

Strongly Disagree

1

2

3

4

Strongly Agree

5

4. The activity was presented objectively and free of commercial bias.

Strongly Disagree

1

2

3
Strongly Agree

5

The opinions expressed by authors contributing to this journal do not necessarily reflect the opinions of the U.S. Department of Health and Human Services, the Public Health Service, the Centers for Disease Control and Prevention, or the authors' affiliated institutions.

For Questions About This Article Contact pcdeditor@cdc.gov

Page last reviewed: June 26, 2014

Page last updated: June 26, 2014

Content source: National Center for Chronic Disease Prevention and Health Promotion

Centers for Disease Control and Prevention 1600 Clifton Rd. Atlanta, GA 30333, USA

800-CDC-INFO (800-232-4636) TTY: (888) 232-6348 - Contact CDC-INFO

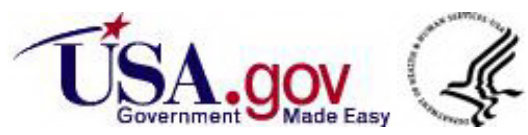

